\title{
Competitiveness Evaluation of Manufacturing Industry based on Weighted Grey Correlation
}

\author{
HuiHu* \\ Economics and Management School, East China Jiaotong University, Nanchang, Jiangxi, China \\ *Corresponding Author.
}

\begin{abstract}
Manufacturing industry is playing an important role in social and economic system, while it is "big but not strong" that is more prominent in developing regions. In order to upgrade manufacturing industry, competitiveness evaluation of manufacturing industry is studied based on weighted grey correlation using analytical hierarchy process and grey correlation analysis. First, statistical data concerned withmanufacturing industry competitiveness are summarized and compared in six developing regions. Then, an evaluation system of manufacturing industrycovering 22 indicators is constructed from economics, scale, $R \& D$ and ecology points of view. Furthermore, by using weighted grey correlation which is combined with analytic hierarchy process and grey correlation analysis methods, a simulation approach considering uncertainty on weight and identification coefficient is developed to make a more reliable assessment. Finally, on the basis of the models and approaches, an empirical study on manufacturing industry competitiveness is carried out and simulation results show that this novel approach can provide information and insights for competitiveness evaluation.
\end{abstract}

Keywords: Competitiveness Evaluation, Weighted Grey Correlation, Simulation Approach, AHP,Manufacturing Industry

\section{Introduction}

As an important sector in a nation's economic system, manufacturing industry has witnessed a rapid development sinceP.R.C founded in 1949, especially reform and open-up policy execution from 1978 to now. Although great achievements have been made, there still exists quite a few shortcomings and disadvantages which are embodied in weak capability of independent innovation, poor resources utilization efficiency and lower industry structure etc. In a word, manufacturing industry is "big but not strong". Consequently, a long-term planning framework for the future manufacturing development called "Made in China 2025"[1] was issued in 2015. In central China, there are six provinces including Hubei, Hunan, Jiangxi, Anhui, and Shanxi, in which their population accounts for 26.5 percent in China. Also, these six provinces are located in an extremely especial geographical region, connecting all directions from west to east and from south to north. With the strategy called "The Rise of Central China" strategy [2] put forward, it's necessary to evaluate manufacturing competitiveness within central China and to point out their advantages and disadvantages so as to help upgrade manufacturing industry and promote their competitiveness.

During the last decades, a good deal of studies on competitiveness evaluation of manufacturing industry have been made which can be classified two categories. One is concerned with theory framework and evaluation indicator system, while the other is relevant to evaluation approaches and methods. For the theory framework and evaluation indicator system, one of researches which have a widely spread influence was an ICOP evaluation framework [3] established by Wageningen university in the Netherlands in 1989. Later, a universally acknowledged paradigm SCP (Structure-Conduct-Performance) is frequently adopted from industrial economics point of view [4]. Based on these theory frameworks, various indicators [5-10] are constructed such as industry performance (output value, productivity, increasing rate), innovation, and sustainability etc. As for the evaluation methods, the kinds of approaches such as shift-share [11], analytic hierarchy process [12], subdivision comparison [13,14], factor analysis [15] and development envelop analysis [16] areemployed to evaluate manufacturing industry

ISSN: 0010-8189

C CONVERTER 2021

www.converter-magazine.info 
competitiveness.

In this paper, we focus on manufacturing industry competitiveness of six provinces in central China. The main contributions of this work lie in that not only isan evaluation indicator system put forward based on SCP paradigm, a novel simulation approach combined analytical hierarchy process with grey correlation analysis is used to give a more reliable evidence for the evaluation. The remainder of the paper is organized as follows. Section II summarizes the current situations of manufacturing industry of six provinces in central China from scale, R\&D, economic efficiency and ecological aspects. Then, an assessment indicator system is constructed based on SCP paradigm and a simulation approach considering uncertainty of weight factor in AHP (analytical hierarchy process) and identification coefficient in GRA (grey correlation analysis) is developed to implement the evaluation process in section III. Hereafter, section IVillustrates the evaluation process and results of manufacturing industry competiveness of six provinces in central China on the assessment indicator system and the simulation approach.Finally, in section V, some conclusions and limitations for this work are summarized and pointed out aimed at our data and approach.

\section{Current Summary of Manufacturing Industry in Central China}

We collect statistics data concerned with manufacturing competitiveness for six provinces in central China including scale, research and development, economical efficiency and ecology benefit during recent five years.

\subsection{Scale}

Scale data includes corporate number, manpower and market share. Here, limited to space, only corporate number is given as Fig 1. As seen from Fig 1, it shows a large scale in six provinces except Shanxi.

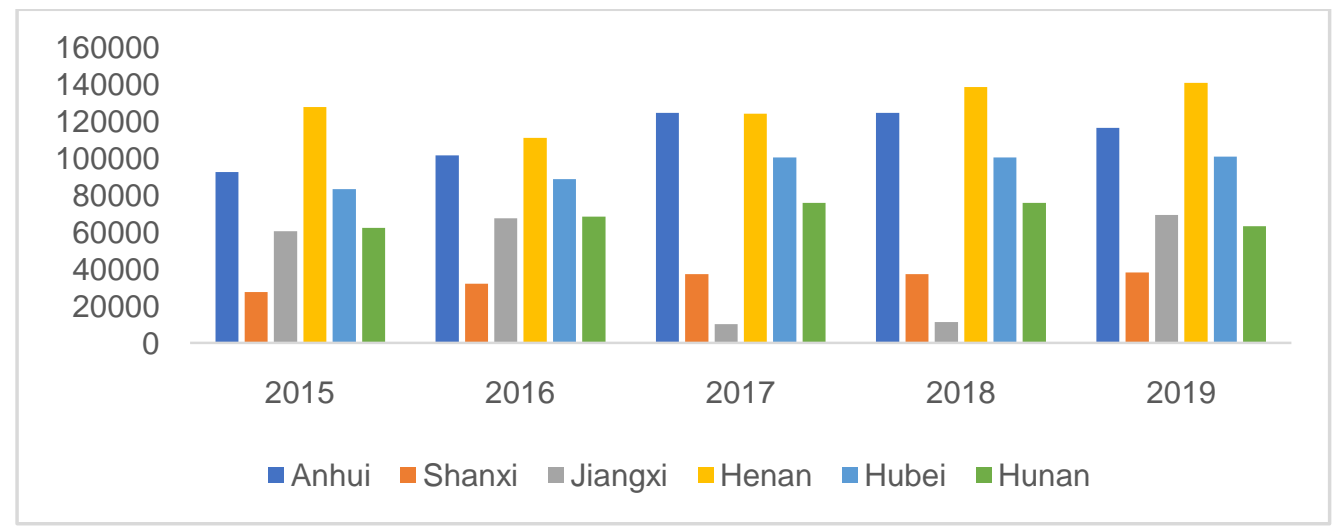

Fig 1: Corporate number of six provinces in central China

\subsection{Research and Development}

We collect R\&D data which includes input and output of six provinces. Also, we just provide two types of R\&D: patent approval rate and $R \& D$ ratio of input to sales revenue (unit is \%).

ISSN: 0010-8189 


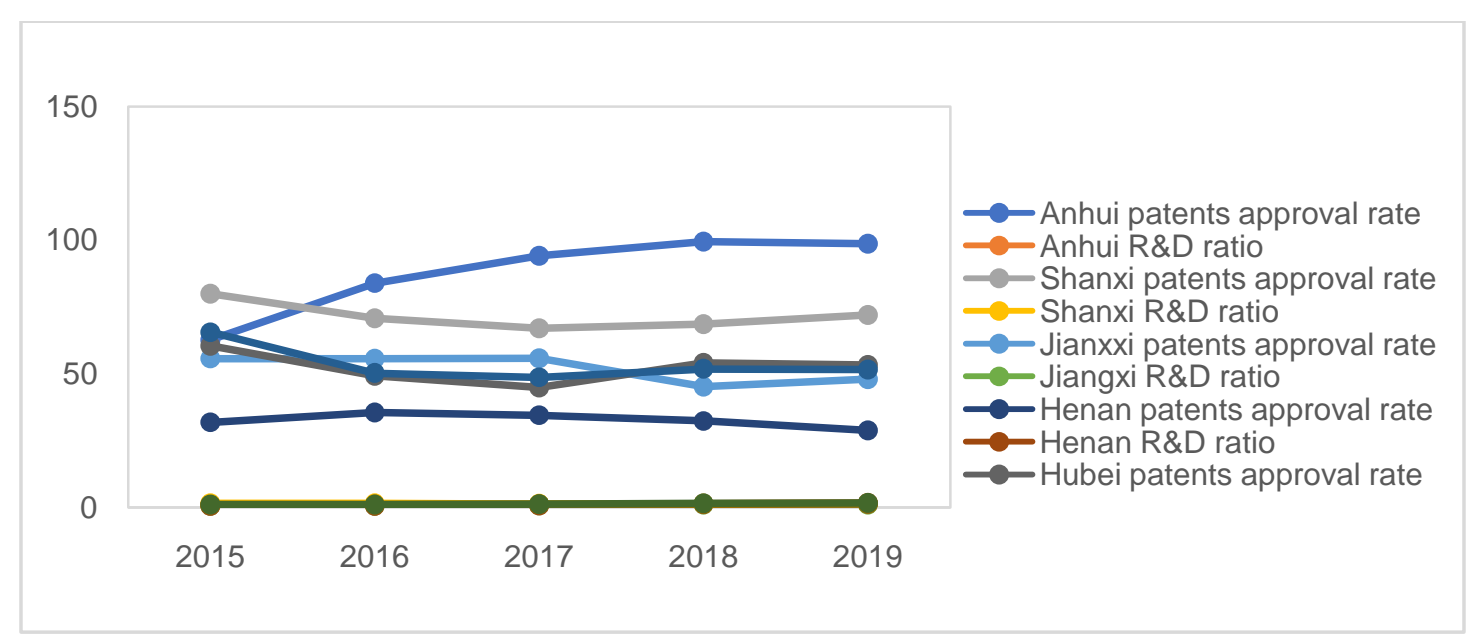

Fig 2: R\&D input and output of six provinces in central China

From Fig 2, it can be seen that Anhui and Shanxi have an advantage over other four provinces in patent approval rate. While, in $R \& D$ input, these six provinces seem nearly the same.

\subsection{Economicefficiency}

Economic efficiency data include investment in fixed assets, operation rate, products qualified rate, profit rate on cost, total asset contribution rate, asset-liability ratio input, main business income-cost ratio and main business income increasing rate etc.We depict them in Fig. 3 followed.

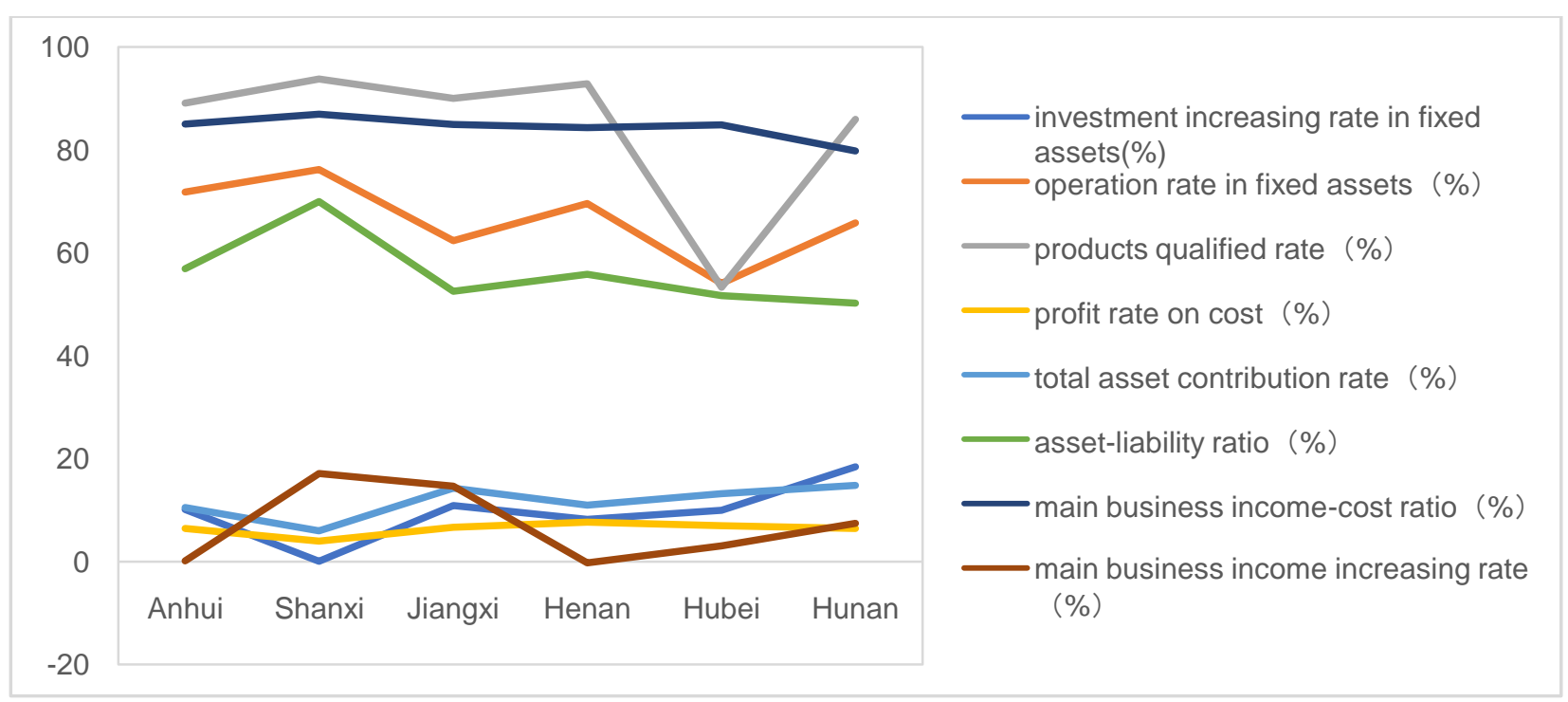

Fig 3: Economical efficiency of six provinces in central China

As seen from Fig. 3, it shows that Jiangxi has some relative potency compared to other five provinces, while products qualified rate in Hubei seems lower.

\subsection{Ecology benefit}

Fig. 4 shows ecology benefit data which are concerned with exhaust emission, waste water production, solid wastes output and investment on industry pollution etc.

ISSN: 0010-8189

www.converter-magazine.info 


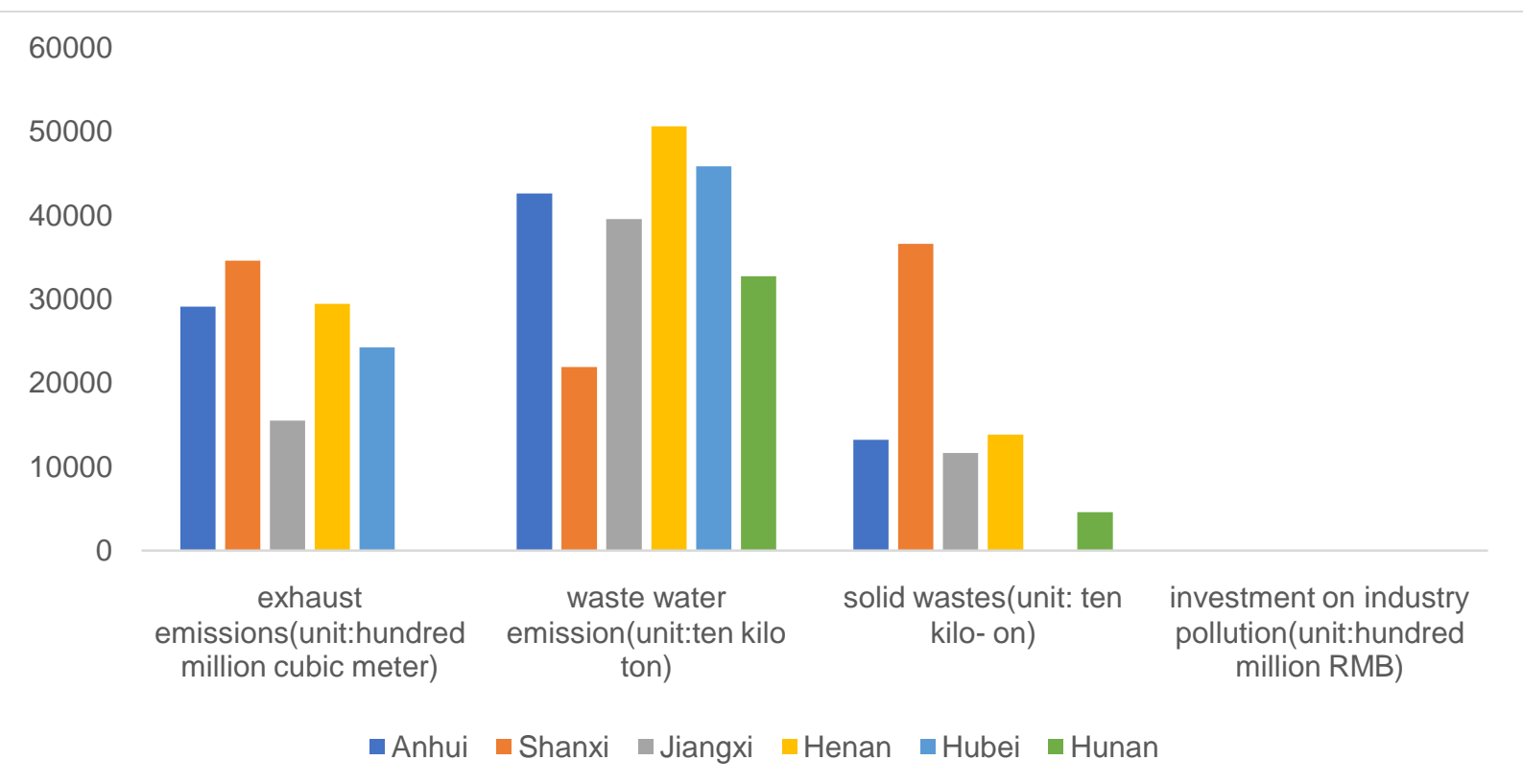

Fig 4: Ecological benefits of six provinces in central China

As seen from Fig. 4, ecology benefit for Shanxi is inferior to other provinces as a whole, while Jiangxi is on the contrary.

\section{Evaluation Indicator System and Approach of Manufacturing industry}

In this section, we attempt to construct an evaluation indicator system and develop a more reliable simulation approach for the assessment of manufacturing industry competitiveness. Simultaneously, in order to get a more reliable evaluation, a simulation approach considering uncertainty of weight in AHP and identification coefficient in GRA is developed based on AHP and GRA.

\subsection{Evaluation indicator system proposed}

Since there is not a clear and unified assessment standard for the manufacturing industry competitiveness, an evaluation indicator system framework as shown in Table 1 is constructed based on SCP paradigm in industrial organizational theory, taking central China location and manufacturing industry characteristics, other experts and scholars' opinions into consideration.

Table 1 Evaluation indicator system for manufacturing industry competitiveness of central China

\begin{tabular}{|c|c|c|c|}
\hline $\begin{array}{l}\text { First level } \\
\text { indicator }\end{array}$ & $\begin{array}{l}\text { Second level } \\
\text { indicator }\end{array}$ & Specific indicator & Unit \\
\hline \multirow{8}{*}{$\begin{array}{l}\text { Economic } \\
\text { efficiency }\end{array}$} & \multirow{4}{*}{ Asset factors } & investment increasing rate of fixed assets & $\%$ \\
\hline & & operation rate of fixed assets & $\%$ \\
\hline & & products qualified rate & $\%$ \\
\hline & & profit rate on cost & $\%$ \\
\hline & \multirow{4}{*}{$\begin{array}{l}\text { Economics } \\
\text { factors }\end{array}$} & total asset contribution rate & $\%$ \\
\hline & & ,asset-liability ratio & $\%$ \\
\hline & & main business income-cost ratio & $\%$ \\
\hline & & main business income increasing rate & $\%$ \\
\hline \multirow{2}{*}{$\begin{array}{c}\text { Scale } \\
\text { efficiency }\end{array}$} & \multirow{2}{*}{$\begin{array}{l}\text { Quantity } \\
\text { factors }\end{array}$} & total population in the year & ten thousand \\
\hline & & number of manufacturing corporate & individual \\
\hline
\end{tabular}

ISSN: 0010-8189

(C) CONVERTER 2021

www.converter-magazine.info 


\begin{tabular}{|c|c|c|c|}
\hline & & $\begin{array}{l}\text { number of industrial enterprises above the } \\
\text { designated size }\end{array}$ & individual \\
\hline & & manpower in manufacturing industry & ten thousand \\
\hline & Market factors & market share & $\%$ \\
\hline \multirow{5}{*}{$\begin{array}{l}\mathrm{R} \& \mathrm{D} \\
\text { efficiency }\end{array}$} & \multirow{3}{*}{ R\&D input } & $\begin{array}{l}\text { proportion of R\&D to manufacturing industry } \\
\text { in the manpower }\end{array}$ & $\%$ \\
\hline & & $\begin{array}{c}\text { proportion of R\&D to whole country in the } \\
\text { manpower, }\end{array}$ & $\%$ \\
\hline & & $\begin{array}{l}\text { proportion of R\&D expenditure to whole } \\
\text { country in the cost }\end{array}$ & $\%$ \\
\hline & \multirow{2}{*}{ R\&Doutput } & patent approval rate & $\%$ \\
\hline & & $R \& D$ ratio of input to sales revenue & $\%$ \\
\hline \multirow{4}{*}{$\begin{array}{l}\text { Ecology } \\
\text { efficiency }\end{array}$} & \multirow{3}{*}{$\begin{array}{l}\text { Pollution } \\
\text { factors }\end{array}$} & exhaust emissions & hundred million cubic meter \\
\hline & & waste water production & ten kilo-ton \\
\hline & & solid wastes output & ten kilo-ton\% \\
\hline & Treatment & investment on industry pollution & hundred million RMB \\
\hline
\end{tabular}

\subsubsection{Economic efficiency}

Economic efficiency is a key element to embody manufacturing industry competitiveness, which can be depicted from two dimensions. One is concerned with assets including investment increasing rate of fixed assets, operation rate of fixed assets, products qualified rate and profit rate on cost. The other is relevant to economics factors including total asset contribution rate, asset-liability ratio,main business income-cost ratio and main business income increasing rate etc.

\subsubsection{Scale efficiency}

For the sake of scale efficiency, quantity and market share indicators are utilized to show manufacturing industry competitiveness. For quantity indicators, total population, manufacturing corporate numbers, numberof industrial enterprises above the designated size and manpower in manufacturing industry. For market factor, marker share is selected as a specific indicator.

\subsubsection{R\&D efficiency}

In the long term, research and development have an impact on manufacturing core competence. We take R\&D input and output to measure manufacturing industry competitiveness. For R\&D input, proportion of R\&D to manufacturing industry in the manpower, proportion of R\&D to whole country in the manpower, proportion of R\&D expenditure to whole country in the cost are selected as indicators. Patent approval rate andR\&D ratio of input to sales revenue arecandidates for R\&D output indicators.

\subsubsection{Ecology efficiency}

Along with sustainability acknowledged more and more, low carbon and green production are gradually awakened to promote manufacturing industry competitiveness. In our evaluation indicator system, ecology efficiency are measured from pollution and treatment dimensions. For pollution dimension, exhaust emissions, waste water production and solid wastes output are specific indicators. And investment on industry pollution is chosen for treatment dimension.

\subsection{Simulation approach based on AHP and GRA}

On the basis of evaluation indicator system, a novel simulation approach using AHP and GRA is developed to assess manufacturing competitiveness of six provinces in central China. In this novel simulation approach, we consider uncertainty on weight of AHP and identification coefficient of GRA. Steps of this simulation approach is depicted as follows;

Step1: Collect the original data of evaluation objects according to evaluation indicator system and normalize data

ISSN: 0010-8189 
since the data's units are different.

Step2: Decide the weights of indicators $\omega_{i}$ using AHP. Different from a unique weight for an indicator, this novel approach considers weight as a random variable which has a probability distribution so that grey correlation coefficient can be computed as a sample.

Step3: Set simulation times.

Step4: Compute grey correlation coefficient using the following formulas.

$\xi_{i}(k)=\frac{a+\rho b}{\left|x_{0}(k)-x_{i}(k)\right|+\rho b}$

$\rho \in[0,1]$

$$
\begin{aligned}
& a=\min _{s} \min _{t}\left|x_{0}(t)-x_{s}(t)\right| \\
& b=\max _{s} \max _{t}\left|x_{0}(t)-x_{s}(t)\right|
\end{aligned}
$$

Here, $\xi_{i}(k)$ is termed by correlation coefficient of a comparative series $x_{i}(k)$ to the reference series $x_{o}(k)$ on the indicator k. Parameter a, b is called two level minimum difference, two level maximum difference respectively. Parameter $\rho$ called identification coefficient is considered to be a uniform random variable in this approach.

Step5: Compute weighted grey correlation degree using the following formula, ranking the evaluation objects.

$r_{i}=\sum_{k=1}^{n} \omega_{i} \xi_{i}(k)$

Step6: Repeat step4-step5 until simulation times are reached.

Step7: Output simulation results such as the rank percentage for evaluation objects.

\section{Empirical Study of Manufacturing Industry Competitiveness for six Provinces in Central China}

According to evaluation indicator system and the novel simulation approach proposed in the above section, we make an empirical study of manufacturing industry competitiveness for six provinces in central China. The original data are collected from China Statistical Yearbook, China Environment Statistical Yearbook, China Industrial Economics, Yearbook and regional yearbooks of six provinces in central China from 2015 to 2019.

\subsection{Standardized evaluation indicator data}

The standardized evaluation indicator data for six provinces in central China are given in Table 2, using formula: $\frac{x_{i}-\mu}{\sigma}(\mu$ is mean of $\mathrm{x}, \sigma$ is standard deviation of $\mathrm{x}$ ).

Table 2Standardized data for six provinces in central China

\begin{tabular}{|c|c|c|c|c|c|c|}
\hline Indicator & Anhui & Shanxi & Jiangxi & Henan & Hubei & Hunan \\
\hline 1 & 0.09009 & 0.16349 & -0.05159 & -0.10317 & -0.07168 & -0.14351 \\
\hline 2 & 0.08790 & 0.16825 & -0.04875 & -0.10134 & -0.06990 & -0.14052 \\
\hline 3 & 0.08728 & 0.16936 & -0.04722 & -0.10065 & -0.06993 & -0.13925 \\
\hline 4 & 0.09022 & 0.16373 & -0.05182 & -0.10319 & -0.07181 & -0.14426 \\
\hline 5 & 0.09008 & 0.16386 & -0.05140 & -0.10309 & -0.07156 & -0.14373 \\
\hline 6 & 0.08843 & 0.16787 & -0.04929 & -0.10175 & -0.07000 & -0.14150 \\
\hline 7 & 0.08743 & 0.16893 & -0.04750 & -0.10090 & -0.06866 & -0.13964 \\
\hline
\end{tabular}

ISSN: 0010-8189

www.converter-magazine.info 
CONVERTER MAGAZINE

Volume 2021, No. 5

\begin{tabular}{|c|c|c|c|c|c|c|}
\hline 8 & 0.09045 & 0.16456 & -0.05138 & -0.10343 & -0.07197 & -0.14420 \\
\hline 9 & 0.16276 & 0.39719 & 0.20535 & 0.22347 & 0.16753 & 0.31673 \\
\hline 10 & 4.05486 & 2.55366 & 3.76676 & 4.09783 & 4.00904 & 3.83314 \\
\hline 11 & 0.49799 & 0.46419 & 0.65026 & 0.39912 & -0.00223 & 0.89933 \\
\hline 12 & -0.08591 & 0.17097 & -0.02247 & -0.06935 & -0.05845 & -0.11773 \\
\hline 13 & -0.08985 & 0.16384 & -0.05129 & -0.10275 & -0.07125 & -0.14355 \\
\hline 14 & -0.08994 & 0.16364 & -0.05209 & -0.10336 & -0.07188 & -0.14444 \\
\hline 15 & -0.09031 & 0.16353 & -0.05204 & -0.10328 & -0.07194 & -0.14445 \\
\hline 16 & -0.09031 & 0.16354 & -0.05206 & -0.10329 & -0.07192 & -0.14440 \\
\hline 17 & -0.09039 & 0.16356 & -0.05213 & -0.10338 & -0.07203 & -0.14456 \\
\hline 18 & -0.08694 & 0.16799 & -0.04954 & -0.10256 & -0.06993 & -0.14142 \\
\hline 19 & -1.12563 & -2.30424 & -0.90874 & -0.98211 & -1.05210 & -0.14739 \\
\hline 20 & -1.60504 & -1.08458 & -2.23546 & -1.61376 & -1.92567 & -2.20622 \\
\hline 21 & -0.55991 & -2.67949 & -0.69601 & -0.51692 & -0.07210 & -0.43413 \\
\hline 22 & -0.08949 & 0.16615 & -0.05160 & -0.10215 & -0.07155 & -0.14432 \\
\hline
\end{tabular}

4.2Weight computation using AHP

We use analytical hierarchy process (AHP) to compute weight as depicted in Table 3. For simplicity, we only assume the probability distribution of first level indicator weight. The uniform distributions is [0.24,0.30], $[0.12,0.20],[0.42,0.50],[0.05,0.12]$ for economic, scale, R\&D and ecology efficiency respectively.

Table 3Indicators' weight for manufacturing industry competitiveness

\begin{tabular}{|c|c|c|c|c|}
\hline $\begin{array}{c}\text { First level } \\
\text { indicator }\end{array}$ & Weight & Second level specific indicator & Sub-weight & $\begin{array}{c}\text { Synthesized } \\
\text { weight }\end{array}$ \\
\hline \multirow{8}{*}{$\begin{array}{l}\text { Economic } \\
\text { efficiency }\end{array}$} & \multirow{8}{*}{0.277} & investment increasing rate of fixed assets & 0.0909 & 0.02519 \\
\hline & & operation rate of fixed assets & 0.0909 & 0.02519 \\
\hline & & products qualified rate & 0.1818 & 0.05039 \\
\hline & & profit rate on cost & 0.1818 & 0.05039 \\
\hline & & total asset contribution rate & 0.0909 & 0.02519 \\
\hline & & ,asset-liability ratio & 0.0909 & 0.02519 \\
\hline & & main business income-cost ratio & 0.0909 & 0.02519 \\
\hline & & main business income increasing rate & 0.1818 & 0.05039 \\
\hline \multirow{5}{*}{$\begin{array}{l}\text { Scale } \\
\text { efficiency }\end{array}$} & \multirow{5}{*}{0.161} & total population in the year & 0.08895 & 0.01433 \\
\hline & & number of manufacturing corporate & 0.1579 & 0.02543 \\
\hline & & $\begin{array}{l}\text { number of industrial enterprises above the } \\
\text { designated size }\end{array}$ & 0.29762 & 0.04794 \\
\hline & & manpower in manufacturing industry & 0.1579 & 0.02543 \\
\hline & & market share & 0.29762 & 0.04794 \\
\hline \multirow{5}{*}{$\begin{array}{l}\mathrm{R} \& \mathrm{D} \\
\text { efficiency }\end{array}$} & \multirow{5}{*}{0.466} & $\begin{array}{c}\text { proportion of R\&D to manufacturing industry in } \\
\text { the manpower }\end{array}$ & 0.15387 & 0.07168 \\
\hline & & $\begin{array}{l}\text { proportion of R\&D to whole country in the } \\
\text { manpower, }\end{array}$ & 0.08808 & 0.04103 \\
\hline & & $\begin{array}{c}\text { proportion of R\&D expenditure to whole } \\
\text { country in the cost }\end{array}$ & 0.08808 & 0.04103 \\
\hline & & patent approval rate & 0.25709 & 0.11976 \\
\hline & & $R \& D$ ratio of input to sales revenue & 0.41288 & 0.19233 \\
\hline \multirow{4}{*}{$\begin{array}{l}\text { Ecology } \\
\text { efficiency }\end{array}$} & \multirow{4}{*}{0.096} & exhaust emissions & 0.2 & 0.01919 \\
\hline & & waste water production & 0.2 & 0.01919 \\
\hline & & solid wastes output & 0.2 & 0.01919 \\
\hline & & investment on industry pollution & 0.4 & 0.03839 \\
\hline
\end{tabular}

4.3Grey correlation coefficient computation using GRA

ISSN: 0010-8189

(C) CONVERTER 2021

www.converter-magazine.info 
Using grey correlation analysis method, we compute a sample of grey correlation coefficients for six provinces in central China in Table 4 (identification coefficient $\rho$ is set 0.5 ). The reference series is the optimal one in evaluation indicator system and the comparative series are six provinces' indicators.

Table 4Grey correlation coefficients of six provinces in central China

\begin{tabular}{|c|c|c|c|c|c|c|}
\hline Indicator & Jiangxi & Shanxi & Henan & Hubei & Hunan & Anhui \\
\hline 1 & 1 & 1 & 1 & 1 & 1 & 1 \\
\hline 2 & 0.998 & 0.998 & 1 & 0.999 & 0.999 & 0.999 \\
\hline 3 & 0.997 & 0.998 & 1 & 0.999 & 0.999 & 0.999 \\
\hline 4 & 1 & 1 & 1 & 1 & 1 & 1 \\
\hline 5 & 1 & 1 & 1 & 1 & 1 & 1 \\
\hline 6 & 0.998 & 0.999 & 1 & 0.999 & 0.999 & 0.999 \\
\hline 7 & 0.997 & 0.998 & 1 & 0.999 & 0.999 & 0.999 \\
\hline 8 & 1 & 1 & 1 & 1 & 1 & 1 \\
\hline 9 & 0.888 & 0.897 & 0.944 & 0.939 & 0.943 & 0.952 \\
\hline 10 & 0.333 & 0.427 & 0.568 & 0.422 & 0.792 & 0.488 \\
\hline 11 & 0.705 & 0.859 & 0.917 & 0.946 & 0.847 & 0.857 \\
\hline 12 & 0.985 & 0.992 & 0.994 & 0.999 & 0.999 & 0.996 \\
\hline 13 & 0.999 & 1 & 1 & 1 & 1 & 1 \\
\hline 14 & 1 & 1 & 1 & 1 & 1 & 1 \\
\hline 15 & 1 & 1 & 1 & 1 & 1 & 1 \\
\hline 16 & 1 & 1 & 1 & 1 & 1 & 1 \\
\hline 17 & 1 & 1 & 1 & 1 & 1 & 1 \\
\hline 18 & 0.999 & 0.998 & 1 & 0.999 & 1 & 0.999 \\
\hline 19 & 0.616 & 0.635 & 0.756 & 0.659 & 1 & 0.686 \\
\hline 20 & 0.403 & 0.714 & 0.692 & 0.536 & 0.699 & 0.625 \\
\hline 21 & 0.681 & 0.602 & 0.868 & 1 & 0.929 & 0.828 \\
\hline 22 & 1 & 0.999 & 1 & 1 & 1 & 1 \\
\hline
\end{tabular}

4.4Weight grey correlation coefficient computation

Using weight of every indicator, weight grey correlation degree is computed 5000 times.Simulation results are summarized in Table 5(identification coefficient $\rho$ is assumed a triangle distribution $[0.4,0.5,0.7]$ ).

Table 5Competitiveness ranking summarization six provinces in central China

\begin{tabular}{|c|c|c|c|c|c|c|c|c|}
\hline & & & Jiangxi & Shanxi & Henan & Hubei & Hunan & Anhui \\
\hline \multirow[t]{7}{*}{ Economic efficiency } & \multicolumn{2}{|c|}{ mean } & 0.9988 & 0.9992 & 1 & 0.99965 & 0.99964 & 0.99963 \\
\hline & \multirow[t]{6}{*}{ rank } & 1 & $0.00 \%$ & $0.00 \%$ & $80.00 \%$ & $10.26 \%$ & $6.52 \%$ & $3.22 \%$ \\
\hline & & 2 & $0.00 \%$ & $0.00 \%$ & $16.24 \%$ & $44.42 \%$ & $27.18 \%$ & $12.16 \%$ \\
\hline & & 3 & $0.08 \%$ & $0.04 \%$ & $3.40 \%$ & $34.70 \%$ & $41.70 \%$ & $20.08 \%$ \\
\hline & & 4 & $1.82 \%$ & $2.20 \%$ & $0.36 \%$ & $10.62 \%$ & $24.28 \%$ & $60.72 \%$ \\
\hline & & 5 & $38.38 \%$ & $57.76 \%$ & $0.00 \%$ & $0.00 \%$ & $0.28 \%$ & $3.58 \%$ \\
\hline & & 6 & $59.72 \%$ & $40.00 \%$ & $0.00 \%$ & $0.00 \%$ & $0.04 \%$ & $0.24 \%$ \\
\hline \multirow[t]{7}{*}{ Scale efficiency } & \multicolumn{2}{|c|}{ mean } & 0.79424 & 0.85713 & 0.90115 & 0.88706 & 0.91638 & 0.87169 \\
\hline & \multirow[t]{6}{*}{ rank } & 1 & $0.00 \%$ & $0.00 \%$ & $14.52 \%$ & $6.54 \%$ & $78.18 \%$ & $0.76 \%$ \\
\hline & & 2 & $0.00 \%$ & $0.02 \%$ & $54.44 \%$ & $21.36 \%$ & $17.12 \%$ & $7.08 \%$ \\
\hline & & 3 & $0.00 \%$ & $0.02 \%$ & $25.82 \%$ & $46.74 \%$ & $4.28 \%$ & $23.14 \%$ \\
\hline & & 4 & $0.00 \%$ & $2.74 \%$ & $5.22 \%$ & $25.24 \%$ & $0.42 \%$ & $66.38 \%$ \\
\hline & & 5 & $0.00 \%$ & $97.22 \%$ & $0.00 \%$ & $0.12 \%$ & $0.00 \%$ & $2.64 \%$ \\
\hline & & 6 & $100.00 \%$ & $0.00 \%$ & $0.00 \%$ & $0.00 \%$ & $0.00 \%$ & $0.00 \%$ \\
\hline
\end{tabular}

ISSN: 0010-8189

(C) CONVERTER 2021

www.converter-magazine.info 
CONVERTER MAGAZINE

Volume 2021, No. 5

\begin{tabular}{|c|c|c|c|c|c|c|c|c|}
\hline \multirow[t]{7}{*}{ R\&D efficiency } & \multicolumn{2}{|c|}{ mean } & 0.9996 & 0.9992 & 1 & 0.9996 & 0.9999 & 0.99963 \\
\hline & \multirow[t]{6}{*}{ rank } & 1 & $2.42 \%$ & $0.00 \%$ & $84.20 \%$ & $0.16 \%$ & $7.78 \%$ & $5.44 \%$ \\
\hline & & 2 & $12.52 \%$ & $0.00 \%$ & $13.52 \%$ & $5.90 \%$ & $41.94 \%$ & $26.12 \%$ \\
\hline & & 3 & $17.92 \%$ & $0.00 \%$ & $2.06 \%$ & $14.22 \%$ & $30.22 \%$ & $35.58 \%$ \\
\hline & & 4 & $29.58 \%$ & $0.08 \%$ & $0.22 \%$ & $29.36 \%$ & $15.72 \%$ & $25.04 \%$ \\
\hline & & 5 & $37.08 \%$ & $1.06 \%$ & $0.00 \%$ & $49.70 \%$ & $4.34 \%$ & $7.82 \%$ \\
\hline & & 6 & $0.48 \%$ & $98.86 \%$ & $0.00 \%$ & $0.66 \%$ & $0.00 \%$ & $0.00 \%$ \\
\hline \multirow[t]{7}{*}{ Ecology efficiency } & \multicolumn{2}{|c|}{ mean } & 0.74 & 0.7898 & 0.8632 & 0.839 & 0.9256 & 0.8278 \\
\hline & \multirow[t]{6}{*}{ rank } & 1 & $0.00 \%$ & $0.00 \%$ & $4.60 \%$ & $0.02 \%$ & $95.38 \%$ & $0.00 \%$ \\
\hline & & 2 & $0.00 \%$ & $0.00 \%$ & $77.78 \%$ & $14.66 \%$ & $4.58 \%$ & $2.98 \%$ \\
\hline & & 3 & $0.00 \%$ & $0.24 \%$ & $13.50 \%$ & $71.90 \%$ & $0.04 \%$ & $14.32 \%$ \\
\hline & & 4 & $0.00 \%$ & $8.28 \%$ & $4.04 \%$ & $13.42 \%$ & $0.00 \%$ & $74.26 \%$ \\
\hline & & 5 & $9.42 \%$ & $82.06 \%$ & $0.08 \%$ & $0.00 \%$ & $0.00 \%$ & $8.44 \%$ \\
\hline & & 6 & $90.58 \%$ & $9.42 \%$ & $0.00 \%$ & $0.00 \%$ & $0.00 \%$ & $0.00 \%$ \\
\hline \multirow{7}{*}{$\begin{array}{l}\text { Comprehensiveevaluati } \\
\text { on }\end{array}$} & \multicolumn{2}{|c|}{ mean } & 0.94138 & 0.95619 & 0.97094 & 0.96602 & 0.97923 & 0.96245 \\
\hline & \multirow[t]{6}{*}{ rank } & 1 & $0.00 \%$ & $0.00 \%$ & $3.12 \%$ & $14.88 \%$ & $72.24 \%$ & $9.76 \%$ \\
\hline & & 2 & $0.00 \%$ & $0.00 \%$ & $30.24 \%$ & $30.56 \%$ & $22.36 \%$ & $16.84 \%$ \\
\hline & & 3 & $0.00 \%$ & $0.00 \%$ & $43.02 \%$ & $33.70 \%$ & $4.88 \%$ & $18.40 \%$ \\
\hline & & 4 & $0.40 \%$ & $2.20 \%$ & $23.62 \%$ & $20.86 \%$ & $0.52 \%$ & $52.40 \%$ \\
\hline & & 5 & $21.86 \%$ & $75.58 \%$ & $0.00 \%$ & $0.00 \%$ & $0.00 \%$ & $2.56 \%$ \\
\hline & & 6 & $77.74 \%$ & $22.22 \%$ & $0.00 \%$ & $0.00 \%$ & $0.00 \%$ & $0.04 \%$ \\
\hline
\end{tabular}

From Table 5, it can be seen that Henan shows an advantage in economics and R\&D efficiency, while Hunan is predominant in scale and ecology efficiency. Hubei and Anhui have potentials to compete in economics efficiency and scale efficiency. As for Jiangxi and Shanxi, there are good spaces of promotion either in economics efficiency or scale efficiency. On the whole, the ranking of comprehensive competitiveness on manufacturing industry is ordered by Hunan, Henan, Hubei, Anhui, Shanxi and Jiangxi.

\section{Conclusion}

With rapid development of social economy in China, six provinces in central China is playing more and more important parts in linking south and north, east and west. Manufacturing industry is considered to be a critical sector in economic system and makes a difference between developing region and developed region. In this paper, using SCP paradigm and weighted grey correlation method, we construct an evaluation indicator system for manufacturing industry and propose a novel simulation approach considering uncertainty of weight in AHP and identification coefficient of GAR. Taking six developing provinces in central China for example model, an empirical study on manufacturing industry competitiveness is carried out and simulation results reveal that Hunan and Henan have some advantages in economics and scale efficiency, while Jiangxi and Shanxi need to upgrade their manufacturing industry in scale and ecology efficiency. Limited to data availability and evaluation methods, further research includes a more appropriate evaluation indicator system, much more data and evaluation approaches.

\section{Acknowledgements}

Undergraduate student of East China Jiaotong University PeiZhang is much appreciated for her work in this research. 


\section{References}

[1] B. Sheng, F. Wei, "Made in China 2025," China Customs, no.8, pp.85, 2014.

[2] Y.J. Cao, "Accurately grasp the connotation of 'rise of Central China'," Study and Practice, no.6, pp.19-23, 2004.

[3] A.Maddison, B.V. Ark, "International comparison of purchasing power, real output and labour productivity: a case study of Brazilian, Mexican and US manufacturing," Review of income and wealth, vol. 35, no. 1, pp. 31-35, 1989.

[4] D.S.Su, "Industrial Economics," Beijing: Higher education press, 2008.

[5] W.H. Yu, "R\&D Growth Performance Differential in Manufacturing across China's Provinces: A Shift-share Analysis”,Forum On Science and Technology In China, no. 10, pp. 61-66, 2013.

[6] X.Y. Lin, "Evaluation system and empirical study of city manufacturing competitiveness," no. 4, pp. 96-99, 2014.

[7] J.W. Shi, W.L. Xie, "Industrial Competitiveness Evaluation and Evolving Trend for Great Powers in the World:2000-2010”, Review of Industrial Economics, no. 9, pp. 1-22, 2015.

[8] Y. Sheng, Y.L. Wang, L. Fan, "World Class Industrial Cluster Selection and Evaluation of the Yangtze River," no. 4, pp. 39-45, 2016.

[9] H.J. Su, J.P. Li, A.Q. Zhu, "Evaluationof Regional Manufacturing Competitiveness in China,’Forum On Science and Technology In China, no. 7, pp. 114-122, 2017.

[10] S.W.Zhu, F.Zhang, "The competitiveness evaluation system for the world class manufacturing clusters," Science\&Technology Review, vol. 38, no. 16, pp. 134-139, 2020.

[11] W.H. Yu, "R\&D Growth Performance Differential in Manufacturing across China's Provinces: A Shift-share Analysis", Forum On Science and Technology In China, no. 10, pp. 61-66, 2013.

[12] H.L. Han, X.Y. Sun, "Competitiveness Evaluation of Advanced Manufacturing Industry based on AHP," China Collective Economy, no. 22, pp. 89-90, 2020.

[13] Y.R. Ma, "Statistical Analysis of Industry Competitiveness in China Regions," no. 8, pp. 86-89, 2002.

[14] L.M. Chen, X. Wang, S.Y. Rao, "Measurement to International Competitiveness of China \& U.S. Manufacturings: Empirical Study Based on Hierarchical View," China Industrial Ecnomics, no.6, pp. 57-66, 2009.

[15] Xiaoyi Qu, Ping Lu, “An Empirical Study of R\&D Influences on Traditional Manufacturing Upgrade”, Statistics and Decision, vol. 36, no.5, pp. 120-123, 2020.

[16] Yu Wang, Junbing Xu, Yang Nan, “The Empirical Study of Regional Manufacturing Competitiveness in China and Influencing Factors,” Journal of Finance and Economics, no. 2, pp. 93-103, 2011. 